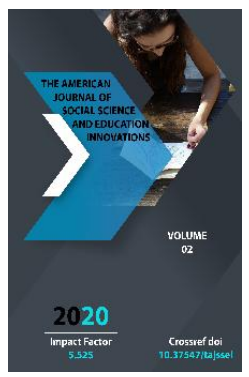

\title{
The Order Of Formation Of Property Rights To Housing On The Basis Of Contracts
}

Journal Website: http://usajournalshub.c om/index,php/tajssei

Muxayyo Ashurova

Independent Researcher At Tashkent State University Of Law, Uzbekistan

\section{ABSTRACT}

These contracts are the most common and widely used yield methods of derivation of property rights in relation to housing. Contracts for the creation of property rights to housing include contracts for the transfer of property under the Civil Code. In civil law, such agreements include contracts of sale, exchange, gift, rent, transfer of housing to another person on the condition of lifetime maintenance. However, the purchase and sale of housing plays an important role in the formation of property rights to housing. Therefore, the main focus in concluding and formalizing a contract for the sale of housing is to ensure the freedom of the parties to enter into a contract. It is important to provide in the legislation that the contract of sale of housing comes into force from the moment of signing by the parties. In addition, the main factor in the protection of the rights of the seller is to determine the current, agreed price of the parties for the sale of housing in the contract. Preventing the simultaneous sale of a house to more than one person, improving the legislation to ensure the rights of the conscientious owner who bought the house, the introduction of the practice of publishing an electronic list of housing sales transactions are relevant today. A special place is given to the fact that non-compliance with the form of the contract of sale of housing is considered a dispute agreement and the introduction of the practice of setting special statute of limitations for the application of its consequences.

\section{KEYWORDS}

Housing, property rights, owner, sale, seller, buyer, right, obligation, legal liability. 


\section{INTRODUCTION}

One way to acquire ownership of a home is through a sale and purchase agreement. Article 386 of the Civil Code defines the contract of sale, according to which, one party (seller) shall transfer goods to the possession to other party (buyer), and the buyer shall accept these goods and pay for it certain sum of money (price). In this regard, even when the house is bought or sold, the house and the property right to it are transferred from one person to another.

Due to the fact that housing is an object of real estate, the provisions of the Civil Code on the sale of real estate shall apply to relations of purchase and sale.

According to Article 479 of the Civil Code, under the contract of sale of real property (contract of sale of real property), the seller undertakes to transfer the land, building, structure, apartment or other real estate to the buyer as property. It is obvious that this norm also envisages an apartment, not a house, as the object of the contract of sale of real estate. In our opinion, this situation is formed on the basis of the requirements of Article 169 of the Civil Code, and the object as in this article is defined as an apartment, not a house. In our opinion, it would be appropriate to use the term "housing" instead of the term "apartment" in Article 479 of the Civil Code.

As a general rule, a contract of sale may be concluded for the purchase and sale of goods available to the seller at the time of the contract, as well as goods created or received by the seller in the future, unless otherwise provided by law (Article 387, Part 2 of the Civil Code). This rule also applies to the contract of sale of housing, which is a type of contract of sale of real estate. In particular, a contract of sale of a house may be concluded for a house that the seller does not have at the time of concluding the contract, or which the seller is constructing or which he is certain to acquire on other grounds.

Housing, which is the object of the contract of sale of housing, is an item marked with special features. According to some legal scholars, real estate is individually defined and irreplaceable. For this reason, it is advisable to sell them in a separate paragraph of the Civil Code[1]. According to O.V. Shvedkova, real estate is not included in the list of items identified by the characteristics of the type, so it is inappropriate to classify them as individually identified it[2]. According to O.Okyulov, since real estate is a property defined by legal features, its exact qualities must be clearly defined in the contract[3]. According to I.B.Zakirov, real estate usually exists permanently in one place and has its own characteristics, special features. For this reason, real estate is not included in the category of items marked by physical features, but in the category of items marked by special features (especially items with unique features, unique, ie items with unique, unique qualities)[4]. In our opinion, in this case, housing, like other objects of real estate, is one of the items marked by special features, and these features and characteristics are taken into account when buying and selling housing.

The legislator does not specify exactly what circumstances should be reflected in the contract as a description of the subject of the contract of sale of a particular apartment, house or room, as well as other objects of housing. However, in practice, the following parameters of housing are determined by the technical inventory authorities in the contract:

1. Last name, first name and patronymic of the owner of the accommodation.

2. The city and the administrative territory in which it is located. 
3. Address, street, house, apartment numbers.

4. Description of the share of the owner (apartment, room, type of property).

5. Document determining the right of ownership in respect of housing.

6. The total area, taking into account the number of rooms, total area, loggia, balcony and living space.

7. The cost of housing in the current year.

Like any civil law contract, a home purchase agreement must contain important conditions that are the basis for the contract to be considered concluded.

Important conditions of the contract of sale of housing, along with the subject of the contract, are the order of valuation and transfer of property. It is known that valuation is not always an important condition in a contract of sale. Article 418 of the Civil Code stipulates that the buyer must pay for the goods at a price determined in accordance with Article 356 of this Code, as well as perform at his own expense the actions necessary to make payment in accordance with the legislation, the contract of sale or general requirements. However, in the contract of sale of housing, the price is always considered as a basic condition, and Article 356, Part 4 of the Civil Code, the rule that "in similar circumstances, for the performance of the contract, the price of such goods, works or services must be paid at the price received, unless the contract provides for a price and cannot be determined by the terms of the contract" does not apply to the contract of sale of housing. The price of housing, which is the subject of the contract of sale, is determined by mutual agreement between the seller and the buyer. Factors influencing the price of housing are mainly related to its geographical location, infrastructure, convenience.
In our country, there are technical inventory bureaus of special state municipal bodies, which carry out the assessment (revaluation) of real estate, the determination of its technical value. However, the value of housing provided by this organization is much lower than its market value, based on the 1969 cost of maintaining the facility and the relevant ratios approved annually by the state technical inventory organization[5]. In our opinion, this situation is a wrong approach from today's point of view. Consequently, setting the value set by the inventory organization at 100 times less than the market value can lead to various abuses and unfair disputes.

For example, a notary formalizes a home purchase agreement with a valuation set by the inventory organization. In practice, however, 150 times the amount was paid. The home purchase agreement was later terminated through the seller's fault (e.g., at the request of the husband or wife). In this case, the court obliges the seller to return the amount received under the contract. The seller returns 150 times less than the actual amount, because the contract simply sets a symbolic price, which is detrimental to the legitimate interests of the buyer. Therefore, in valuing housing, it would be advisable to bring its value closer to the market price.

Of course, in the process of drawing up a contract of sale of housing, the notary is included in the notarized part of the text of the contract that the notary is not responsible for the discrepancy between the current price of the house and its current price. However, in most cases, the misinterpretation by notaries leads the parties to try not to set the agreed price of housing in the contract. In most cases, notaries arbitrarily include the price of the contract in the contract without asking the parties for the price of the contract of sale. This can eventually lead to various conflicts. 
Therefore, when drawing up a contract of sale of housing, notaries require the parties to write in the contract the agreed price, explain that this situation does not lead to any additional fees or state duties, fees for registration of housing are determined not on the basis of the price of housing, but on the basis of its area, in the future in case of dispute the buyer can demand only the amount specified in the contract. Unfortunately, in today's practice we can see the opposite of this situation. Therefore, if the buyer later discovers unexpected, hidden defects in the house and demands the unilateral termination of the contract, he will be able to receive only the "symbolic amount" specified in the contract, and not the amount actually paid. In order to eliminate these cases, the Republic of Uzbekistan adopted the Regulation "On the procedure for notarization of real estate transactions" and explained the consequences of notarial work and actions to be taken by notaries to determine the transaction price. the inclusion of the situation in which the signatures of the confirming parties have been obtained must be reflected. According to Part 3 of Article 485 of the Civil Code, unless otherwise provided by law or the contract of sale of immovable property, the value of the building, structure or other immovable property located on the land plot shall include the price of the relevant part of the land plot or the right to it. Even when a house is purchased, the land on which it is located is included in the contract price.

If in the contract of sale of real estate the price of the property is determined by its unit of area (for example, 500 soums per 1 sq.m.) or other indicator (for example, the number of fruit trees in the steam), the total price to be paid determined based on the current amount. Consequently, in such cases, the general value of the property does not have to be fixed. For example, if the apartment 20 sq.m. is sold, the price of the apartment is set at 200,000 soums, if the price is agreed at 10,000 soums per square meter and is reflected in the contract[6].

One of the existing problems in today's practice related to a home purchase agreement is the sale of a single home to more than one person at a time. This is due, firstly, to the lack of legal awareness and literacy of citizens, and secondly, to the mistakes made in notarial acts. In most cases we can see that one dwelling is sold to several persons at the same time as the subject of many agreements such as bequest, transfer of housing to another person on the condition of lifelong maintenance, gift and sale, rent, exchange. The current Civil Code establishes general rules for notarization of transactions. However, the $\mathrm{CC}$ does not determine under what legislation the notarization of the transaction is carried out, what the notary should pay attention to when approving the transaction. At the same time, the Law of the Republic of Uzbekistan "On Notaries" provides a general definition of the procedure for registration of real estate transactions, as well as the procedure for registration of ordinary transactions. Therefore, it would be expedient to include in Article 110 of the Civil Code, which establishes the rules of notarization of the transaction, as part 2, the rule "the procedure for notarization of the transaction is determined by special legislation".

Selling one apartment to two or more people at the same time is a typical form of fraud, in this case, the person prepares two or more housing documents and gives them to the buyer, may receive money from them in advance or delay the notarization of the transaction in writing. Consequently, when a notary sells a house, the fact that the house was sold to another person on the basis of this purchase is included in the general 
register, and this house is not allowed to be registered in the name of another person through a contract of sale. In order to prevent the sale of one dwelling to two or more persons, notarization of such contracts and the notary's right to request all details of the legality of this transaction are the right of every person to be promoted and explained, for a notarized contract of sale non-payment must be explained to citizens by notary offices.

One of the important conditions of the contract of sale of housing is the transfer of this housing to the buyer. The term "transfer" is the implementation of concerted actions for the transfer of a particular object from one subject to another. As a result of the transfer of housing, the original owner (seller) of the thing loses the right of ownership over this property, and this right is acquired by another (buyer).

\section{CONCLUSION}

The procedure for handing over the house to the buyer follows from the provisions of Article 486 of the Civil Code. According to it, the transfer of real estate by the seller and its acceptance by the buyer is carried out in accordance with the deed of transfer or other document on transfer, signed by the parties. Unless otherwise provided by law or the contract, the obligation of the seller to transfer the real property to the buyer is considered fulfilled after the transfer of the property to the buyer and the signing of the relevant document on the transfer.

An important condition of the contract of sale of a house, apartment, house or part of an apartment inhabited by persons specified in Article 488 of the contract of sale of housing and according to which the seller retains the right to use the apartment building in accordance with the law after purchase to make a list of the rights to use the residential building for sale. The contract of sale of a house, apartment, part of a house or apartment must be notarized and registered by the state.

This procedure is also established by the legislation of the Russian Federation, and according to D.A.Jdan-Pushkin, the main condition of the contract of sale of housing is a list of residents and their consent to the sale of housing[7].

According to parts 2-3-4 of Article 14 of the Housing Code, the contract of sale and exchange of a house, apartment is concluded in writing by preparing a single document signed by the parties and must be notarized and registered by the state.

Failure to comply with the form of the contract of sale of the house, apartment will result in its invalidity. An important condition of the contract of sale of the apartment, in which the buyer resides the right to use the dwelling after the purchase, is to compile a list of persons with the right to use the dwelling for sale.

\section{REFERENCES}

1. Valyavina E.Yu. Civil law: Textbook. Part 2 / Under. ed. A.P. Sergeeva, Yu.K. Tolstoy.M .: Prospect, 1998.-94 p.

2. Shvedkova O.V. Acquisition and implementation of citizens' ownership of residential premises. Dis ... Candidate of Legal Sciences-M .: 2004.-83 p.

3. Civil law. The second part./ Under the general editorship of H.Rahmonkulov and I.Zokirov.-Tashkent: Ilm Ziyo, 2008.-91 p.

4. Comments on the Housing Code of the Republic of Uzbekistan.-Tashkent: TSU, 2007.-38 p.

5. Shvedkova O.V. Acquisition and implementation of citizens' ownership of 
residential premises. Dis ... Candidate of Legal Sciences-M .: 2004.-85 p.

6. Civil law. The second part./ Under the general editorship of H.Rahmonkulov and I.Zokirov.-Tashkent: Ilm Ziyo, 2008.-91 p.

7. Zhdan-Pushkina D.A. Contract of purchase and sale of real estate.-M .: EKSMO, 2006.-15 p. 